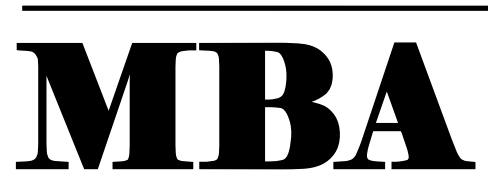

Vol. 5, No. 1, January 2022, page $463-474$

ISSN 2614-1981 (Print)

ISSN 2615-0352 (Online)

Journal of Management and Business Aplication

\title{
PRODUCT QUALITY CONTROL ANALYSIS BY USING STATISTICAL PROCESSING CONTROL ON PRINTING SAKILA JEMBER
}

\author{
Ahmad Sauqi ${ }^{1}$ \\ Helmi Agus Salim ${ }^{2}$ \\ Saiful Amin ${ }^{3}$ \\ Higher Education of Economic Mandala, JL. Sumatera No 118-120 Jember 68121, Indonesia ${ }^{1,2,3}$
}

Received : 2021/10/14 Corresponding author:

Revised : 2021/10/28 Name: Ahmad Sauqi

Accepted : 2021/11/04 E-mail: sauqi@stie-mandala.ac.id

\begin{abstract}
The pandemic has made many businesses out of business, one of the affected business activities is Sakila's printing business. Initial surveys show an average of $4.46 \%$ of production damage. The direction of this research is to control quality with statistical aids in the form of SPC. The results showed that this printer experienced various deviations, as evidenced by the $\mathrm{p}$ chart value which was still outside the control limit. The graphic map showed there were 17 points outside the control limit. The total damage from 6 product items for a month amounted to 4543 from a total production of 70,647. Sequentially, the worst damage was in the opaque damage 2740, the damage was not in accordance with the layout 1008 and the damage due to being cut was 795 . The factors causing the damage were workers, production machines, raw materials, work methods and the work environment.
\end{abstract}

Keywords: Quality; Product; Statistical; Processing; Control.

\section{INTRODUCTION}

Jember Regency is a Regency that has many advantages, starting from its big name as a tobacco-producing city, a city of art which is famous for its JFC (Jember Fashion Carnaval) and various other advantages, especially the rapid development in the field of economy and education.

The very rapid development of education makes Jember district a reference for knowledge seekers to study in this city, one of the goals for studying is Jember State University and various other universities in this district. Various Islamic boarding schools in Jember district also play a role so that Jember becomes a destination for religious studies. 
The rapid development of education in this district has created various new business opportunities ranging from boarding houses, culinary businesses, printing and so on. This new business opportunity will certainly be responded to very quickly by business people, especially in developing areas such as Jember Regency. It is no longer a secret that if an area becomes an education center, the price of land around the education center will increase in price because business people will definitely think of starting a new business, both in the field of providing products and services. The number of students who stay temporarily in an area because they are studying will provide opportunities for boarding house owners to make profits as well as for culinary and printing businesses.

The number of public and private universities in Jember district has indeed become one of the supporters of the acceleration of the economy in this district. We will see a lot of businesses in areas close to campus, before the Covid-19 pandemic these businesses were full of enthusiasm in trying to get the desired profit, but after the pandemic, many of these businesses have gone out of business due to very weak market conditions. Consumers are decreasing because they mostly go home and do lectures online. Weak market conditions can also be seen from the declining purchasing power of consumers.

One of the affected business activities is the printing business, it is undeniable that after the pandemic, many activities involving people directly began to decrease or even do not exist, for example national seminars and international seminars. These activities are carried out online, which of course no longer requires banners, seminar kits and so on.

One of the printing presses affected but still surviving today is Sakila's printing press. This printing press tries to survive in the pandemic era in various ways, one of which is by picking up the ball in providing services to customers. CV. Sakila started trying to rise from adversity during the pandemic, in this new normal era, CV. Sakila started picking up the ball to get various orders from cutomers who can already subscribe to this printing press.

CV. Sakila or Sakila printing service serves various community needs related to the printing of brochures, invitations, notes, books, calendars, business cards, id cards and the binding of theses, theses and dissertations. Sakila Printing will directly carry out the orders that have been mentioned earlier because they have the machines or production equipment to carry out such orders. Other orders, such as billboards, will be sub-submitted to partner printers, but the design will be done by the printing design department of Sakila Jember.

Sakila Printing is located in Patrang District, Jember Regency and was established in 2003 and already has a trade business license and company registration certificate. Based on the initial survey, the owner of Sakila printing said that there were several complaints related to the quality of the products produced, these complaints were part of customer dissatisfaction with the products received. We all know that if the value of the benefits felt by the customer is the same as their expectations or exceeds their expectations, it is certain that the customer will feel satisfied, but on the other hand, if the value of the perceived benefits is below expectations, the customer will be disappointed or dissatisfied. The owner of the Sakila printing press also submitted data regarding defective products during production in January 2021 and according to the person concerned, it is usually not this much in the previous months.

The level of damage to the production of several products produced by Sakila Jember printing is still quite high, if we average it still reaches $4.46 \%$. The highest level of defective production is in the Memorandum production and the ID Card production does not experience any defects at all. 
Measuring how much product damage level that can be tolerated by a company by determining the tolerance limit of the resulting product defects can be done using quality control methods in the form of statistical tools. Quality control method which in its activities uses statistical tools contained in Statistical Process Control (SPC) and Statistical Quality Control (SQC) where the quality of the production process is controlled from the beginning of production, during the production process until the finished product. Before being sold to the market, products that have been produced are checked first, good products are separated from defective products. The need for Statistical Processing Control is due to the difference in quality (quality dispersion) between products with the same type, the same process sequence, produced on the same machine, the same operator and environmental conditions, and this problem always arises in manufacturing companies that produce in large quantities. .

It is commonplace that consumers want quality products at competitive prices, from what was experienced by Sakila Jember printing, there is a business phenomenon that is quite well appointed for further research in order to provide benefits for business actors.

The direction of this research leads to quality control with statistical tools that are useful for monitoring the level of efficiency, so that later it can be used as a tool for detection that tolerates damage and prevention that avoids / prevents defects from occurring. Detection is usually carried out on finished products and prevention is carried out as early as possible so that defects in the product can be prevented.

\section{RESEARCH METHODS}

According to Heizer and Render (2014: 244), quality is: "The totality of the features and characteristics of a product or service that uses its ability to meet the promised and implied needs." Control according to Sofjan Assauri (2008:38) Control or supervision is a function of ensuring that activities are carried out as planned, so that the aims and objectives for the use and management of inputs can in fact be carried out.

Statistical quality control using SPC (Statistical Processing Control) has 7 main statistical tools that can be used as tools to control quality as written by Heizer and Render in their book Operations Management (2006: 263-268), among others, namely; check sheets, histograms, control charts, pareto diagrams, cause-and-effect diagrams, scatter diagrams, and process diagrams.

Statistical Processing Control is a statistical technique that is widely used to ensure that processes meet standards. In other words, apart from Statistical Process Control is a process used to monitor standards, make measurements and take corrective actions while a product or service is being produced. (Render and Heizer: 2006). Some of the benefits of Statistical rocessing Control, among others, are for supervision, prevention of deviations in the process and can reduce inspection costs.

The conceptual framework in this research illustrates how statistical quality control can analyze the level of damage/defects of products produced by Sakila Jember printing which exceed the tolerance limit and identify the causes of these problems to be traced to produce proposals/ recommendations for improving production quality in the future. Here we describe the conceptual framework. 


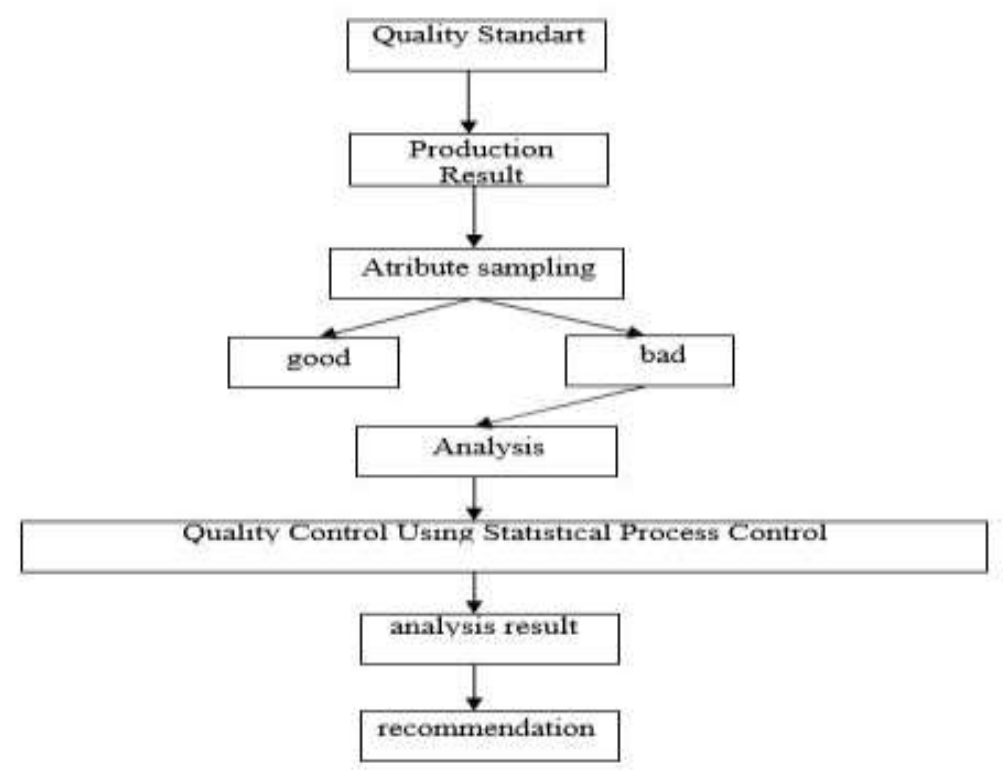

Figure 1. Conceptual framework

Quality control is aimed at achieving the level of product quality standardized by Sakila Jember Printing in accordance with the quality guidelines set by Sakila Jember Printing. The implementation of quality control at Sakila Jember printing is carried out by attributes, namely quality measurements of product characteristics that cannot or are difficult to measure. The characteristics referred to here are good or bad product quality, success or failure. Attribute quality measurement is carried out using a control chart ( $\mathrm{p}$-chart) or commonly called a p-control chart, a p-control chart is used in attribute quality control, namely to identify defects or defects in the resulting product and to determine whether still within the required limits.

The population in this research is Sakila Jember's printing press which has an unknown number of damage/defects, both recorded and missed from quality observations until it reaches consumers. Sampling in this study using purposive sampling technique. Purposive Sampling is a sampling technique using certain considerations (Sugiyono, 2018). The sample used in this research is the Sakila Jember printing press which was found to be damaged/defective so that it did not reach consumers.

Data Collection Method: Interviews are one way to get detailed information from the research conducted, we interviewed employees or managers of Sakila Jember printing press. Observation is a direct observation on the object of research in this case the production activities at Sakila Jember printing, observations in the form of the production process from beginning to end and how the process of controlling the quality of the products produced. Documentation is part of studying the data or information owned by the Sakila Jember printing company so that it is possible to obtain findings that can support more objective research results and can be useful for the Sakila Jember printing house. Processing of research data is carried out using tools available in Statistical Processing Control (SPC). Here are the processing steps:

1. Collect production data and damaged products (Check Sheet)

The data obtained from the Sakila Jember printing house, especially production data and damaged product data, were processed into a neat and structured table. This is done to make it easier to understand the data so that further analysis can be carried out. 
2. Create a Histogram

In order to make it easy to read or explain the data quickly, it is necessary to present the data in the form of a histogram in the form of a visual data presentation tool in the form of a graphic block showing the distribution of the values obtained in the form of numbers.

3. Create a P-chart (P-chart)

Analysis of research data using $\mathrm{p}$ control chart (damage proportion control chart) as a tool for statistical process control. The use of this p control chart is because the quality control carried out is attribute, as well as the data obtained which is used as a sample for non-permanent observations and products that are damaged can be repaired again so they must be rejected. According to (Render and Heizer: 2006) there are 4 steps in making a p control chart. The following are the steps in making a p control chart.

a. Calculating Damage Percentage

$$
p=\frac{n p}{n}
$$

Description:

$\mathrm{np}$ : Number of failures in sub group

$\mathrm{n}$ : Number of checked in sub group

Sub group : Day-

b. Calculating the center line (CL)

The center line is the average product damage ( $\mathrm{p}$ )

$C L=\bar{p}=\frac{\sum n p}{\sum n}$

Description:

$\mathrm{np}=$ Total Number of Damaged

$\mathrm{n}=$ Total Number Checked

c. Calculating the Upper Control Limit (UCL)

$$
U C L=\bar{p}+3\left(\sqrt{\frac{\bar{p}(1-\bar{p})}{n}}\right)
$$

Description:

$\overline{\mathrm{p}}=$ average product damage

$\mathrm{n}=$ total group/sample

d. Calculating the lower control limit (LCL)

$$
L C L=\bar{p}-3\left(\sqrt{\frac{\bar{p}(1-\bar{p})}{n}}\right)
$$

Description:

$\overline{\mathrm{p}}=$ average product damage

$\mathrm{n}=$ number of production

If $\mathrm{LCL}<0$ then LCL is considered $=0$

If the data obtained are not entirely within the specified control limits, this means that the data taken is not uniform. It states that the quality control carried out by Sakila Jember printing still needs improvement. This can be seen on the p-chart, if there are points that fluctuate irregularly which indicates that the production process is still experiencing deviations. With this control chart, it is possible to identify the types of damage to the 
products produced and the types of damage that occur to the various types of products produced.

4. Finding the most dominant causal factor with a cause-and-effect diagram

After knowing the most dominant main problem using a histogram, then a product damage factor analysis is carried out using a fishbone diagram, so that it can analyze what factors are the cause of product damage.

5. Make recommendations/proposals for quality improvement

After knowing the cause of product damage, a recommendation or proposed action can be made to improve product quality.

\section{RESULT ANALYSIS}

SAKILA Jember Printing is located in Patrang sub-district, this printer is engaged in services, especially in producing stationery needs or office equipment which in the production process prints using paper media and the end result is in accordance with what consumers want. The marketing areas in all regencies as ex-Besuki residency are Jember, Banyuwangi, Situbondo, Bondowoso and Lumajang regencies. Sakila Printing was established in 2003, with the following business legalities:

a. Trading Business License : No. 503/804/436,314/2007

b. Company Registration Certificate : No. 13.07.3.52.02222

c. Taxpayer Identification Number : No. 02.664.222.3-626.000

Production results in this service company vary depending on consumer demand. The byproduct of this business unit is the installation of billboards, billboards, banners, and banners at events of major holidays. The main raw material is paper in addition to other supporting facilities, including tracing, Repro, plates, and cutting tools. Personal quantity development (especially non-permanent employees, couriers, and print operators) will be carried out if necessary according to the company's business needs.

Table 1. Details of Sakila Printing Workforce in 2021

\begin{tabular}{llc}
\hline No. & \multicolumn{1}{c}{ Description } & Amount \\
\hline & Permanent employees: & \\
1. & Leader & 1 \\
2. & Head of production & 1 \\
3. Part Finance \& Administration & 2 \\
4. Graphic designer & 2 \\
5. Non-permanent Employees: & \\
6. Marketing & 2 \\
7. Machine Operator / Print Operator & Machine Operator Assistant / Print Operator & 2 \\
8. Finishing Power & 5 \\
9. Courier & 2 \\
\hline & & 2 \\
\hline
\end{tabular}

Source: Sakila Jember Printing 2021 
The leader or manager of the Sakila Jember printing press has the obligation to ensure the smooth and successful business activities of the Sakila Jember printing press. The Head of Production has the task of coordinating all production activities carried out at the Sakila Jember printery.

The finance and administration department is tasked with ensuring the smooth recording of incoming and outgoing financials, they are also obliged to record all activities, both transaction and operational activities in Sakila's printing business. The graphic design employee is obliged to fulfill the customer's wishes regarding the desired print out in every order. Graphic design employees are required to ask the customer first before printing activities are carried out, for example in brochure printing and so on.

Marketing department employees who are non-permanent employees will focus more on target marketing because their salary depends on the number of sales they generate. The machine operator is in charge of ensuring the smooth running of the printing activities carried out, the machine operator is fully responsible for the printing process. Assistant machine operators or print operators are tasked with assisting machine operators during printing activities.

The finishing employee is in charge of checking, packing and so on before the goods are sent by courier to the customer. Couriers are in charge of ensuring that the goods arrive at the customer's hands in good condition according to when they were packed by the finishing department. Inspection is carried out for the implementation of quality control. Quality control in the form of inspection will of course be matched with Sakila Jember's printing standards, meaning whether it meets the standards or not. In accordance with the previous discussion that there are 6 product items that are produced on a large scale, namely brochures, invitations, notes, books, calendars and id cards. Sakila Printing sets the quality standards of the 6 products, including;

1. The prints of the 6 product items must be clear and not blurry when read, meaning that the ink absorption must be evenly distributed.

2. The printouts of the 6 product items must match the position according to the initial design that has been agreed upon, meaning that it must match the layout.

3. The prints of the 6 product items must not be cut, the cuts must be in accordance with the cut limit when designing is done so that folding can be easily done, for example in a brochure.

Data Analysis: Check Sheet table is data obtained from Sakila Jember printing, especially production data and damaged product data processed into a neat and structured table. This is done to make it easier to understand the data so that further analysis can be done.

Table 2. Report of Production and Daily Damaged Products of Sakila Jember Printing During January 2021.

\begin{tabular}{cccccc}
\hline Date & $\begin{array}{c}\text { Total Production } \\
\text { of 6 Products }\end{array}$ & Blur & $\begin{array}{c}\text { Type of Defect } \\
\text { Layout }\end{array}$ & Cut off & $\begin{array}{c}\text { Number of } \\
\text { Defective } \\
\text { Products }\end{array}$ \\
\cline { 3 - 6 } & 14550 & 400 & 152 & 90 & 642 \\
2 & 0 & 0 & 0 & 0 & 0 \\
3 & 2000 & 42 & 17 & 41 & 100 \\
4 & 540 & 25 & 5 & 1 & 31 \\
5 & 200 & 7 & 3 & 2 & 12 \\
6 & 0 & 0 & 0 & 0 & 0 \\
7 & 1500 & 40 & 15 & 5 & 60
\end{tabular}




\begin{tabular}{|c|c|c|c|c|c|}
\hline \multirow[b]{2}{*}{ Date } & \multirow[b]{2}{*}{$\begin{array}{l}\text { Total Production } \\
\text { of } 6 \text { Products }\end{array}$} & \multicolumn{3}{|c|}{ Type of Defect } & \multirow{2}{*}{$\begin{array}{l}\text { Number of } \\
\text { Defective } \\
\text { Products }\end{array}$} \\
\hline & & Blur & $\begin{array}{l}\text { Not Fit } \\
\text { Layout }\end{array}$ & Cut off & \\
\hline 8 & 8775 & 425 & 125 & 160 & 710 \\
\hline 9 & 7000 & 185 & 65 & 50 & 300 \\
\hline 10 & 250 & 8 & 2 & 1 & 11 \\
\hline 11 & 105 & 3 & 0 & 0 & 3 \\
\hline 12 & 7700 & 500 & 150 & 100 & 750 \\
\hline 13 & 4300 & 100 & 60 & 37 & 197 \\
\hline 14 & 0 & 0 & 0 & 0 & 0 \\
\hline 15 & 5300 & 200 & 180 & 20 & 400 \\
\hline 16 & 50 & 1 & 0 & 0 & 1 \\
\hline 17 & 4000 & 155 & 45 & 19 & 219 \\
\hline 18 & 252 & 5 & 2 & 2 & 9 \\
\hline 19 & 0 & 0 & 0 & 0 & 0 \\
\hline 20 & 100 & 5 & 1 & 2 & 8 \\
\hline 21 & 4000 & 196 & 24 & 33 & 253 \\
\hline 22 & 0 & 0 & 0 & 0 & 0 \\
\hline 23 & 285 & 15 & 0 & 0 & 15 \\
\hline 24 & 50 & 0 & 2 & 0 & 2 \\
\hline 25 & 6000 & 325 & 82 & 175 & 582 \\
\hline 26 & 0 & 0 & 0 & 0 & 0 \\
\hline 27 & 0 & 0 & 0 & 0 & 0 \\
\hline 28 & 300 & 18 & 0 & 0 & 18 \\
\hline 29 & 0 & 0 & 0 & 0 & 0 \\
\hline 30 & 350 & 5 & 8 & 3 & 16 \\
\hline 31 & 3040 & 80 & 70 & 54 & 204 \\
\hline Total & 70647 & 2740 & 1008 & 795 & 4543 \\
\hline Average & 2279 & 88 & 33 & 26 & 147 \\
\hline
\end{tabular}

Source: Sakila Jember Printing, 2021

Based on this histogram, it is clear that the most frequent damage is blurry production results where uneven ink absorption causes unclear print results. The number of blurry defects is 2,740 copies and the following is followed by production defects due to not conforming to the layout of 1008 copies and 795 copies being cut off.

P Control Map ( P-Chart ): Calculating Damage Percentage, microsoft Excel can be used as a tool in calculating the percentage of damage because if it is calculated manually, of course it will be quite time-consuming.

Table 3. Total Production, Damaged Products and Percentage of Damaged Products

\begin{tabular}{|c|c|c|c|c|c|c|}
\hline \multirow[t]{2}{*}{ Date } & \multirow{2}{*}{$\begin{array}{c}\text { Total } \\
\text { Production of } \\
6 \text { Products }\end{array}$} & \multicolumn{3}{|c|}{ Type of Defect (Copies) } & \multirow{2}{*}{$\begin{array}{l}\text { Number of } \\
\text { Defective } \\
\text { Products }\end{array}$} & \multirow{2}{*}{$\begin{array}{l}\text { Percentage of } \\
\text { Defective } \\
\text { Products (\%) }\end{array}$} \\
\hline & & Blur & $\begin{array}{l}\text { Not Fit } \\
\text { Layout }\end{array}$ & Cut off & & \\
\hline 1 & 14550 & 400 & 152 & 90 & 642 & 4.4 \\
\hline 2 & 0 & 0 & 0 & 0 & 0 & 0 \\
\hline 3 & 2000 & 42 & 17 & 41 & 100 & 5 \\
\hline
\end{tabular}




\begin{tabular}{|c|c|c|c|c|c|c|}
\hline \multirow[t]{2}{*}{ Date } & \multirow{2}{*}{$\begin{array}{c}\text { Total } \\
\text { Production of } \\
6 \text { Products }\end{array}$} & \multicolumn{3}{|c|}{ Type of Defect (Copies) } & \multirow{2}{*}{$\begin{array}{l}\text { Number of } \\
\text { Defective } \\
\text { Products }\end{array}$} & \multirow{2}{*}{$\begin{array}{l}\text { Percentage of } \\
\text { Defective } \\
\text { Products }(\%)\end{array}$} \\
\hline & & Blur & $\begin{array}{l}\text { Not Fit } \\
\text { Layout }\end{array}$ & Cut off & & \\
\hline 4 & 540 & 25 & 5 & 1 & 31 & 5.7 \\
\hline 5 & 200 & 7 & 3 & 2 & 12 & 6 \\
\hline 6 & 0 & 0 & 0 & 0 & 0 & 0 \\
\hline 7 & 1500 & 40 & 15 & 5 & 60 & 4 \\
\hline 8 & 8775 & 425 & 125 & 160 & 710 & 8.1 \\
\hline 9 & 7000 & 185 & 65 & 50 & 300 & 4.3 \\
\hline 10 & 250 & 8 & 2 & 1 & 11 & 4.4 \\
\hline 11 & 105 & 3 & 0 & 0 & 3 & 2.9 \\
\hline 12 & 7700 & 500 & 150 & 100 & 750 & 9.7 \\
\hline 13 & 4300 & 100 & 60 & 37 & 197 & 4.6 \\
\hline 14 & 0 & 0 & 0 & 0 & 0 & 0 \\
\hline 15 & 5300 & 200 & 180 & 20 & 400 & 7.5 \\
\hline 16 & 50 & 1 & 0 & 0 & 1 & 2 \\
\hline 17 & 4000 & 155 & 45 & 19 & 219 & 5.5 \\
\hline 18 & 252 & 5 & 2 & 2 & 9 & 3.6 \\
\hline 19 & 0 & 0 & 0 & 0 & 0 & 0 \\
\hline 20 & 100 & 5 & 1 & 2 & 8 & 8 \\
\hline 21 & 4000 & 196 & 24 & 33 & 253 & 6.3 \\
\hline 22 & 0 & 0 & 0 & 0 & 0 & 0 \\
\hline 23 & 285 & 15 & 0 & 0 & 15 & 5.3 \\
\hline 24 & 50 & 0 & 2 & 0 & 2 & 4 \\
\hline 25 & 6000 & 325 & 82 & 175 & 582 & 9.7 \\
\hline 26 & 0 & 0 & 0 & 0 & 0 & 0 \\
\hline 27 & 0 & 0 & 0 & 0 & 0 & 0 \\
\hline 28 & 300 & 18 & 0 & 0 & 18 & 6 \\
\hline 29 & 0 & 0 & 0 & 0 & 0 & 0 \\
\hline 30 & 350 & 5 & 8 & 3 & 16 & 4.6 \\
\hline 31 & 3040 & 80 & 70 & 54 & 204 & 6.7 \\
\hline Total & 70647 & 2740 & 1008 & 795 & 4543 & \\
\hline Average & 2279 & 88 & 33 & 26 & 147 & 6.5 \\
\hline
\end{tabular}

Source: Sakila Jember Printing, 2021

Calculating the Center Line, Based on the above formula, the value of the Central Line is 0.0643. Calculating Upper Control Limit and Lower Control Limit, Based on the above formula, the value of UCL 0.1965. Based on the above formula, the value of LCL -0.0679. The following will present a picture of the $\mathrm{p}$ chart as the next series of processes after the values of cl, ucl and lcl are known. 


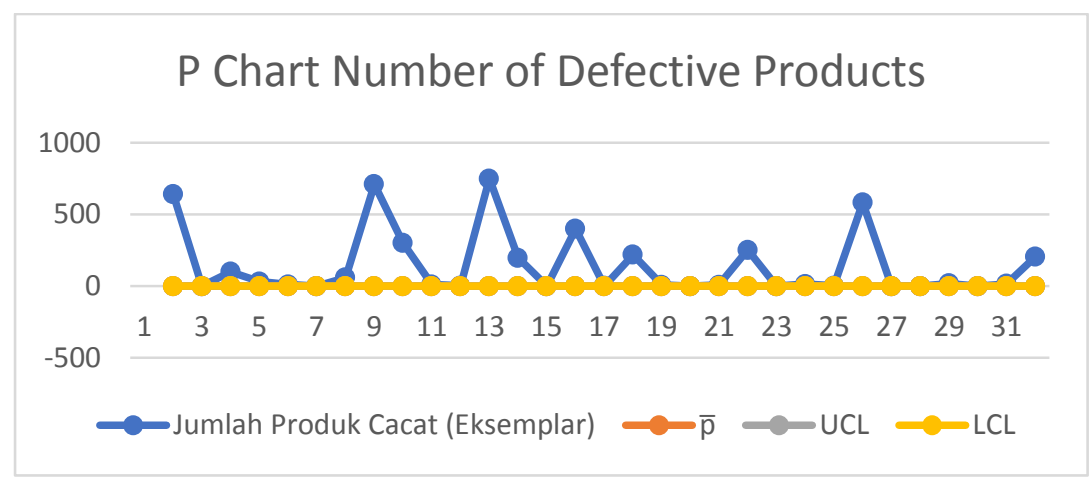

Figure 2. P Chart Control Map

Based on the $\mathrm{P}$ control map or $\mathrm{P}$ chart, we can see that there are still 17 points that are outside the control limit, especially above the UCL limit, so from here it can be judged that the process is not being constrained. The printing process at Sakila Jember Printing is still experiencing irregularities. This deviation can still be analyzed again using a causal diagram so that later it can be known what causes the deviation.

Blurry prints are certainly not suitable for sale or delivery to consumers. Damage in the form of blur can be caused by ink that is not well absorbed, usually at the beginning of printing the ink is still thick in the sense that it is not too liquid and this can cause the printout to look blurry. The amount of ink can also be a factor in blurry print results, the wrong amount of ink can occur due to the lack of attention of workers. Furthermore, checks related to machine settings also need to always be checked so that there are no blurry prints.

The position of the layout of the printed output that is shifted and does not match the initial design that has been done previously is a damage that must be carefully corrected. This problem is caused by workers who are less focused on managing machines, employees who are less focused can be caused by many things, one of which is a hot room temperature so that machine operators are disturbed. The most important part is that before carrying out a large-scale printing process, it is better for the head of the production department to hold a meeting first.

Starting from brochures, notes, calendars, invitations that are cut off according to the layout will make the product defective and not function properly. This truncated problem can be caused by operators who are less focused in checking machines or cutting tools. Cutting tools or cutting machines sometimes have a dull knife and this needs periodic checks. Another thing is the same as above, namely the room temperature must be made comfortable and not too hot or too cold because this will interfere with operator performance.

The head of production must periodically check the performance of his subordinates to provide encouragement and guidance in order to minimize errors in production so that the product is not defective. Ink inspection must be checked in detail and attempted to use ink according to the machine specifications. Periodically also machine maintenance must be done by providing time to check the machine operation carefully.

It's a good idea to add a fan in the printing room because after all the hot conditions will make the employee's focus will decrease. Next, the head of production must often conduct briefings so that employees always remember their responsibilities and of course briefings must be carried out in a relaxed manner and do not need to use a high tone let alone be angry.

Provide facilities that make the workforce more focused on work, for example mining fans so they don't get hot. If the sound system can provide additional enthusiasm, it can be added with the sound of music that does not need to be too loud, the point is that the workforce does not feel 
bored and bored. Next, machine checks and maintenance must be carried out on a scheduled basis even though the machine is not damaged because this will minimize more severe engine damage. Machines that are always ready to operate will certainly produce products that are not defective.

\section{INTERPRETATION}

Production activities at Sakila Jember's printing press are in an uncontrolled condition as evidenced by the $\mathrm{p}$ chart values which are still outside the control limits, the graphic map also shows that there are about 17 points outside the control limits. Total damage from 6 product items for another month was 4543 from a total production of 70,647. Sequentially, the worst damage was in the opaque damage 2740, the damage did not match the layout of 1008 and the damage due to being cut was 795 . The factors that caused the damage were workers, production machines, raw materials, work methods and the work environment.

Overcoming this, the Leader can brief employees regarding each employee, then employees must always be reminded to always work professionally and responsibly. Leaders must provide solutions as asked by employees who do not understand them, including solutions to problems others who are still within the scope of work at Sakila's printery. Perform regular machine maintenance even though the machine is in normal condition, this is part of prevention before a complete messian occurs. A comfortable atmosphere must of course be built at work, this can be supported by adequate facilities and infrastructure. Good treatment for employees increases employee morale, for example in the form of bonuses

\section{CONCLUSION}

The process of printing activities at Sakila Jember's printing press is in an uncontrolled condition because it is still experiencing various irregularities. This is evidenced by the $\mathrm{p}$ chart value which is still outside the control limit, the graphic map also shows that there are about 17 points outside the control limit.

The total damage from 6 product items for a month amounted to 4543 from a total production of 70,647. Sequentially, the worst damage was in the opaque damage 2740, the damage was not in accordance with the layout 1008 and the damage due to being cut was 795 . The factors causing the damage were workers, production machines, raw materials, work methods and the work environment.

\section{IMPLICATIONS}

The Sakila Jember printing leader is advised to frequently conduct briefings to employees regarding the responsibilities of each employee, then employees must always be reminded to always work professionally and responsibly. Leaders must provide solutions if employees ask about parts of the task that they do not understand, including solutions to other problems that are still within the scope of work at Sakila's printing press.

Perform regular machine maintenance even though the machine is in normal condition, don't wait for a damaged machine to be repaired. Periodic maintenance and checks are useful for knowing the health of the parts on the machine so that if you find a part that is not good enough, it can be replaced immediately so that the damage does not spread to other parts.

Make the working atmosphere as comfortable as possible, in this case it is the leader's obligation to convey to the owner to provide supporting infrastructure for the convenience of employees at work, for example adding a fan, providing a sound system for listening to songs and so on. 
Give bonuses to employees if the level of damage or product defects can be minimized. Bonuses are not always in the form of money, they can also be in the form of goods such as clothes, t-shirts, batik or maybe food. The point is to make employees feel at home to work and have no desire to move to another place. Build a good family atmosphere for the owner, leader and subordinates.

\section{REFERENCES}

Assauri, Sofjan. 2008. Manajemen Produksi dan Operasi.Jakarta: Fakultas Ekonomi Universtias Indonesia.

Davies, K. 2005. Human Behavior at work Organizational Behavior. New Delhi: McGraw Hill Publishing company.

Gaspersz, Vincent. 1997. Manajemen Kualitas. Jakarta: PT. Gramedia Pustaka utama.

Heizer dan Render. 2006. Manajemen Operasi. Jakarta: Salemba Empat.

Kotler, Philip. 2005. Manajemen Pemasaran. Jilid 1 dan 2. Jakarta : PT Indeks Kelompok Gramedia.

Kadir,Abdul.2001. Dasar Pemrograman Web Dinamis Menggunakan PHP. Yogyakarta Penerbit Andi.

Lovelock,C and Wirtz,J.2004. Services Marketing. Fifth Edition. Prentice Hall: New Jersey. Rogers, Everett M. 1995. Diffusion of Innovations (Fourth Edition). The Free Press. New York.

Scherkenbach, Wiliam W., Deming's.1991. Road to Improvement. SPC Press Inc. Knoxville Tennessee.

Stanton J William,1993, Prinsip Pemasaran, Edisi 7 Jilid 1. Edisi Terjemahan Oleh Yohanes Lamarto. Erlangga,: Jakarta.

Sugiyono. 2018. Metode Penelitian Kuantitatif, Kualitatif, dan R\&D. Bandung: Alfabeta.

Sunyoto, Danang. 2014. Dasar-Dasar Manajemen Pemasaran (Konsep, Strategi, dan Kasus). Cetakan ke-1. Yogyakarta: CAPS (Center for Academic Publishing Service).

Tjiptono,Fandy. 2004. Manajemen Jasa. Edisi Pertama. Yogyakarta: Andi Offset.

Tjiptono,Fandy.2011. Service, Quality \& Satisfaction. Edisi 3. Yogyakarta: Andi Offset. 